\title{
Notes on Some Japanese Fungi
}

\author{
By
}

\section{Takewo Hemmi}

(With 5 text-figures)

I. Clavaria Miyabeana Iто: Nom. Jap. Beni-naginata-take (Fig. 1)

Hab. On the ground in woods. Kyoto (Aug. 3, 1931, A. Tsuchida; Oct. 15, 1931, S. Akai and I. Matsuura).

This fungus is easily distinguished from other known species of Clavaria by its beautiful red colour. The description of this fungus was first published by Imar (7) in 1930 and, so far as the writer knows, the present paper is the second record of the collection of this fungus. According to IMAI two specimens of this fungus, both collected at the lake side of Kuttcharo in Hokkaidô, are preserved in the Herbarium of Hokkaidô Imperial University. The writer has two specimens of the same fungus in his herbarium, both collected in Kyoto during this year at different places. From these facts, the writer may draw the interesting conclusion that the fungus is widely distributed through provinces of Honshû as well as on the main Island of Hokkaidô.

The color of the plants collected by TsuCHIDA was similar to "Strawberry Pink", "Scarlet" and especially

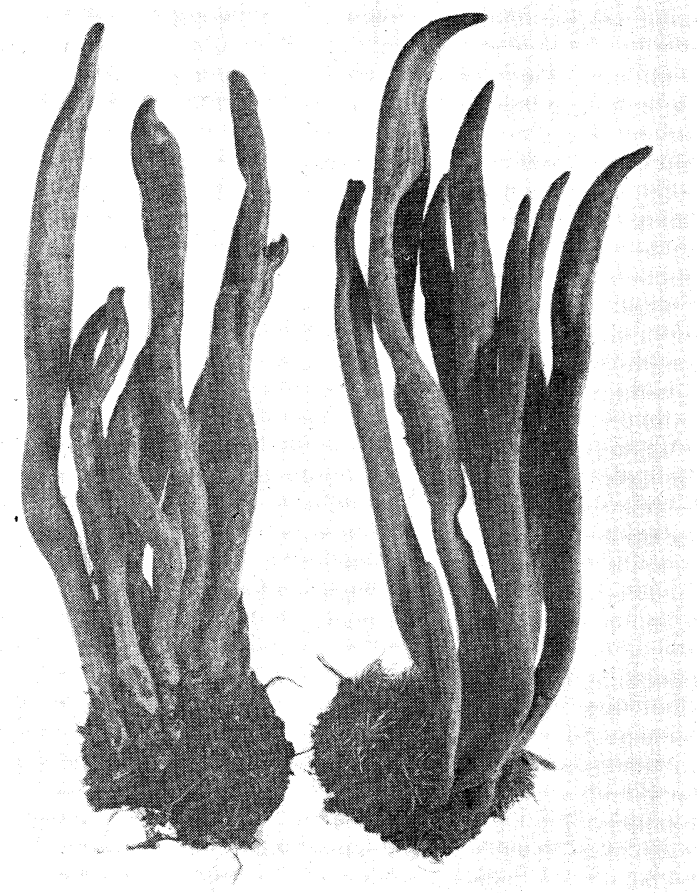

Fig. 1 Clavaria Miyabeana Iто

* Contributions from the laboratories of Phytopathology and Mycology, Kyoto Imperial University, K yoto, Japan. No. 59. 
to "Peach Red" in a fresh condition, changing to "Salmon Orange" or to " Orange" (RIDGWAy) after drying. But the other specimens were more or less abnormal in color, when the writer examined them, chiefly owing to their drying condition. The spores are almost hyaline, smooth, subspherical with a minute mucro and are 5.0 to $7.2 \mu$ in diameter.

\section{Clavaria amethystinoides PECK: Nom. Jap. Murasaki-} Hôkitake-modoki (nov.) (Fig. 2)

Hab. On the humus soil under trees. Kyoto (July $6 \& 14,1931$, S. Aкаг; July 24, 1931, T. Hеммг), Iwakura-mura near Kyoto (July 15, 1931, K. Matsuo).

This fungus is very commonly found in July in the vicinity of Kyoto. Basing his conclusions on the study of a specimen found at

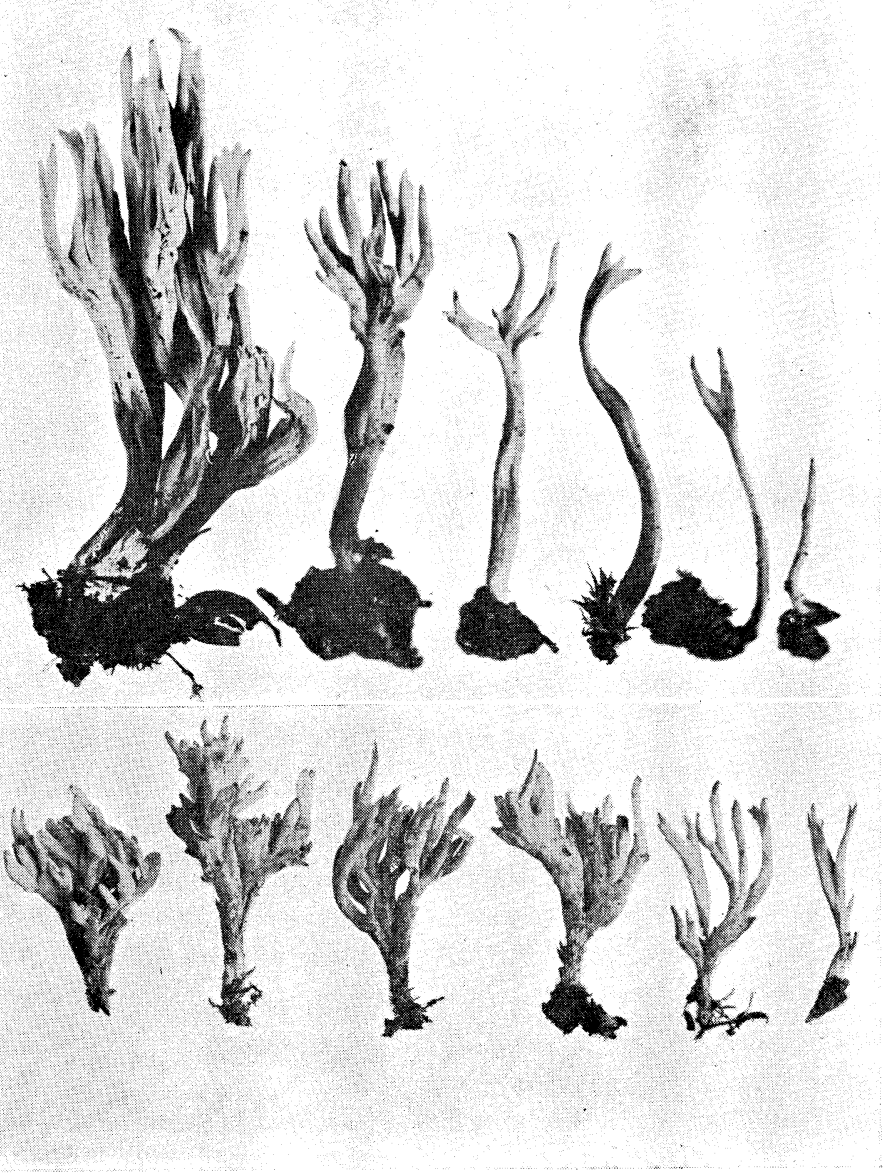

Fig. 2 Clavaria amethystinoides PECK 
Stow, Massachusetts, Peck (9) published a diagnosis of the fungus in 1907, as a new species. The color, as well as the shape of the fruit bodies of the present fungus, tends to show some variation owing to growing conditions. The writer has carefully compared the descriptions given by Peck (9), Saccardo (14), Burt (1) and also by Coker (2) with his plants and tinds them similar.

The plants are for the most part single, but are sometimes gregarious growing together in scant numbers, 1 to $6 \mathrm{~cm}$. tall, distinctly stalked, usually antlered or palmately branched with a few rather short suberect branches; the tips are commonly acute. They show a "Pale Flesh Color" or a "Pale Lilac" becoming "Drab Gray" (RrdGway) or darker according to their drying. The stems are generally a little darker than the branches. Spores are hyaline, smooth, almost spherical and 6.5 to $8.6 \mu$ in diameter. Each basidium has two sterigmata. The fungus is a new addition to the mycological flora of Japan.

\section{Clavaria acuta Sow.: Nom. Jap. Shiro-yari-take.}

Hab. On the ground in woods. Iwakura-mura near Kyoto (Oct. 12, 1929, K. Matsuo).

Basing his conclusions on a collection found at the lake side of Shikotsu in Hokkaidô on September 23, 1929, Imar (7) reported the fungus as a species added to the mycological flora of Japan. Preceding his publication, the writer also had studied the same fungus, collected at Iwakura-mura near Kyoto in October of the same year. The fact that those two places are far apart from each othar shows the fungus to be common and widely distributed throughout Honshû and Hokkaidô. The plant is easily distinguished by its slender white fruit bodies having 1 to $2.5 \mathrm{~cm}$. height. The spores are hyaline, smooth, subspherical with a distinct apical mucro and 5.34 to $10.68 \mu$ in diameter.

IV. Pleurotus porrigens (Pers.) Fr.: Nom. Jap. Sugi-hiratake (nov.) (Fig. 3)

Hab. On the bark of the living trunks or on the decaying stumps of Cryptomeria japonica Don. Mt. Hiei, Kyoto (Sept. 30, 1930, I. Hino); Mt. Atago,. Kyoto (Oct. 24, 1930, T. Heмmi); Kiyotaki, Kyoto (Oct. 18, 1931, T. Неммі).

The plant is snow white and sessile, growing on decaying stumps or sometimes on the bark of the living trunks of Cryptomeria japonica in the vicinity of Kyoto. Judging from the descriptions given by the European authors $(3,10,11,12,15)$ the fungus seems to grow only on - coniferous stumps. The fruit bodies are first resupinate and exceedingly 
small, growing gradually, however, to a moderate size. The largest plant preserved in the writer's herbarium is $7 \times 5 \mathrm{~cm}$. in size. The grown plants are ear-shaped, narrow at the base, dilating above with undulated lobes. The margin of the pileus shows a tendency to roll slightly toward the underside. The rills concur mostly in an umbilicus, but are decurrent occasionally, being very narrow and crowded. The upper side of the pileus is almost smooth near the margin and tomentose to-

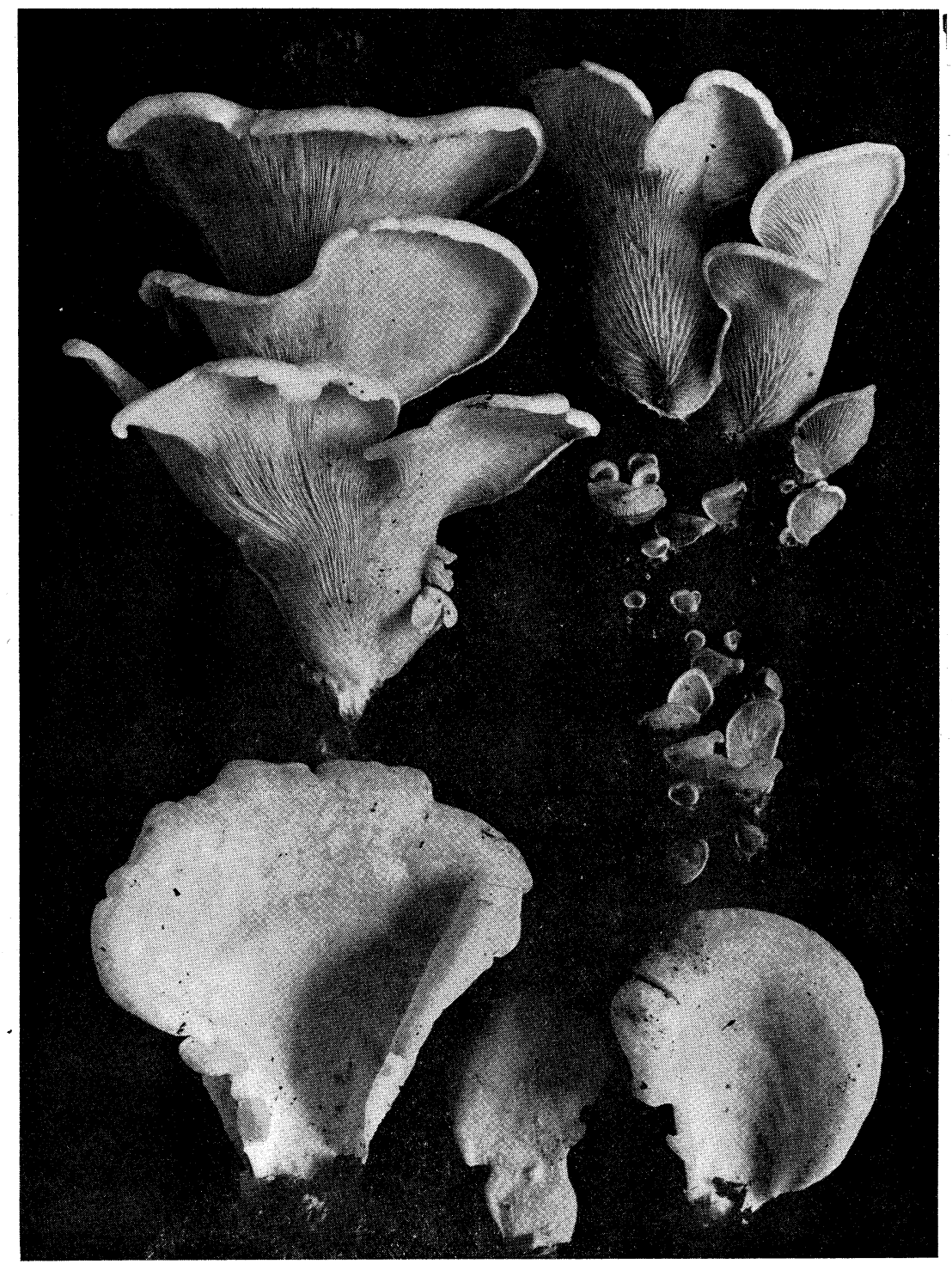

Fig. 3 Pleurotiss porrigens (Pers.) Fr. 
wards the basal portion. These morphological characters are identical with those of Pleurotus porrigens, which was illustrated by Cooke (4).

The plant grows singly or clustered and imbricated, that is, they overlap. They may all arise separately from the wood, and yet be overlapping, though oftener several of them are closely joined or united at the base. The flesh of the pileus is white and thin. Spores are hyaline, globose to subglobose and measure $3.5-5.4 \mu$ in diameter or $4.3-7.0 \times 3.5-5.4 \mu$ in size. The spore-dimension of the fungus in question is smaller than that in the European descriptions $(11,12)$. However, SACCARdo (12) noted its dimension as $7-8 \times 6$ or $6 \times 4 \mu$, the latter case being similar to the writer's measurement. This is also a new addition to the mycological flora of Japan.

\section{Femsjonia luteo-alba Fr.: Nom. Jap. Nikawa-take (nov.)}

Hab. On the bark of decaying wood. Mt. Hiei, Kyoto (Nov. 23, 1929, S. Konishi).

The genus, Femsjonia, belongs to Dacryomycetaceae, and includes only a few species. Femsjonia luteo-alba is a rare plant and has not, as far as the writer knows, been collected in Japan. The writer's specimens were found in a wet condition and accordingly the shape of the fruiting bodies seemed to be a little abnormal. They were gelatinous, erumpent, sessile and yellow in color. Their sizes were rather small, being commonly 10 to $15 \mathrm{~mm}$. in diameter. One of them was, however, exceedingly large. They were mostly convex and folded, becoming wrinkled. Spores are hyaline to yellowish, boat-shaped, oblong or allantoid with attenuated ends, $19.2-48.0 \mu$ in length and 9.6-14.4 $\mu$ in width.

They are first one celled and multi-guttulate, but becoming later 8 to 15 or more-septate. The spores of the fungus in question are a little larger than those of the European material described by REA (11) and Killermane (8). However, the agreement of other characters with those given by several authors $(8,11,13)$ has led the writer to recognize the fungus as Femsjonia luteo-alba Fr.

VI. Clavaria pyxidata Pers.: Nom. Jap. Fusa-himehôkitake (nov.) (Fig. 4)

Hab. On rotten wood. Mt. Hiei, Kyoto (Sept. 9, 1928, H. HAMAda); Iwakura-mura near Kyoto (Oct. 9, 1929, K. MAtsuo).

The plants grow in tufts reaching 5 or $6 \mathrm{~cm}$. in height. They are 
pallid and then become tan color or dull ochraceous. The main stem is slender, dividing into several branches which spread out rather widely and then turn up again; the ultimate branch expanding at their tips into little cups from the margins of which spring the branchlets radiately, the terminal ones dentate. The spores are hyaline, ovate, ellipsoidal to pip-shaped, sometimes spherical and $2.67-4.50 \times 2.2-2.9 \mu$ in size. Comparing the above characteristics with those described by many authors $(1,2,11)$, the writer has come to believe the fungus in question to be Clavaria pyxidata. Pens. The fungus is easily recognized by the cup-shaped expansions at the end of the branches and by small hyaline spores. As far as the writer knows, this is also a first record of this fungus in Japan.

VII. Clavaria Kunzei Fr.: Nom. Jap. Shiro-hime-hôki-take (Fig. 5)

Hab. On the ground in woods. Mt. Kurama near Kyoto (Oct. 9, 1929, T. Аве); Iwakura-mura near Kyoto (Oct. 12, 1929, K. Matsuo).

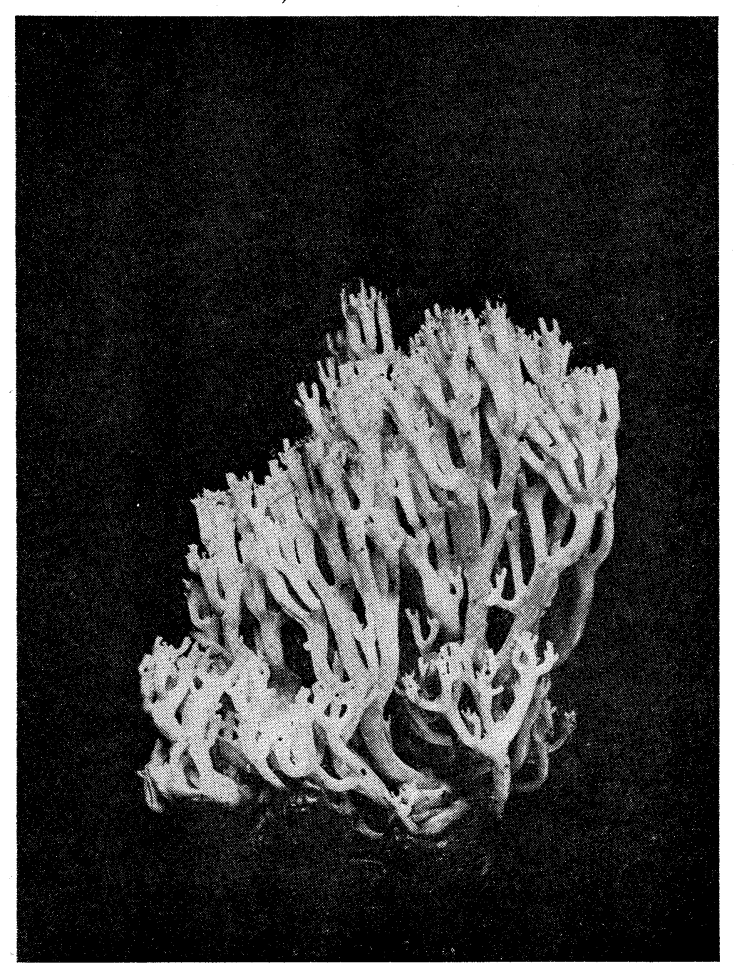

Fig. 4 Clavaria pyxidata Pers.

This is a well marked species of Clavaria distinguished easily by its smallsized, white-colored and branching fruit bodies, generally being characterized by delicate and pretty appearance. The first report of this fungus in Japan was published by ImaI (6) in 1929, and according to him he hadcollected the fungus at Nopporo in Hokkaikô. Since the writer has also two collections from different places near Kyoto, the fungus seems to be distributed very widely throughout Honshû as well as Hokkaidô.

The spores of the specimens preserved in the writer's herbarium are hyaline, mostly subspherical, sometimes short 
ellipsoidal or pointed at one end, minutely asperulate and $2.64-5.34 \times$ $2.64-4.20 \mu$ in size. The characters of the writer's specimens are similar to those described by Cotton and Wakefield (5), Burt (1) and also Coker (2).

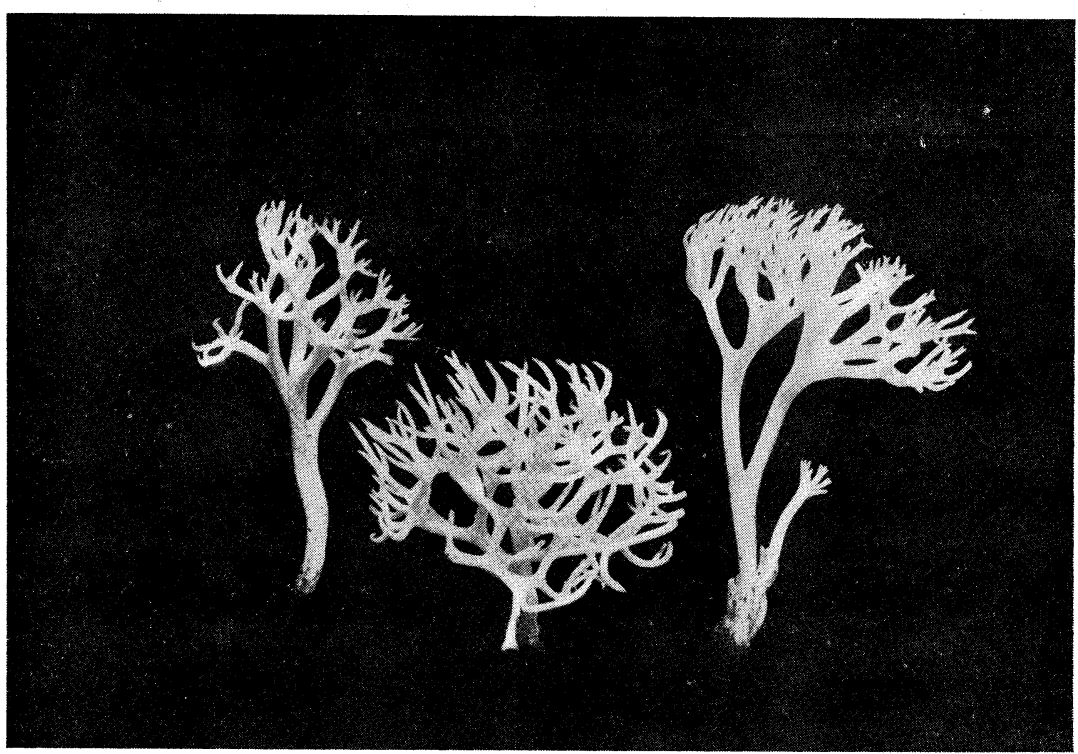

Fig. 5 Clavaria Kunzei FR

Finally the author wishes to express his hearty thanks to the persons who kindly contributed the valuable collections to his herbarium, and particular thanks are due to Mr. K. Matsuo and to Miss. S. KuRATA for their kindness in assisting his works.

November 25, 1931

$$
\begin{aligned}
& \text { College of Agriculture, } \\
& \text { Kyoto Imperial University, } \\
& \text { Kyoto, Japan }
\end{aligned}
$$

Literature cited

1. Burt, E. A.: The North American Species of Clavaria with Illustrations of the Type Specimens. Annals Missouri Bot. Gard., Vol. IX, p. 1-78, 1922.

2. Coker, W. C.: The Clavarias of the United States and Canada. p. 65-67, p. 2527, 1923.

3. Cooke, M. C.: Handbook of British Fungi. p. 50, 1871. 
4. Cooke, M. C. : Illustrations of British Fungi. Vol. II, Pl. 259, 1881-1883.

5. Cotton, A. D. and Wakefield, E. M.: A Revision of the British Clavariae. Trans. British Myc. Soc., Vol. VI, p. 164-198, 1920.

6. ImaI, S.: On the Clavariaceae of Japan. Trans. Sapporo Nat. Hist. Soc., Vol. XI, p. 38-44, 1929.

7. ImaI, S. : On the Clavariaceae of Japan. II. Trans. Sapporo Nat. Hist. Soc., Vol. XI, p. 70-77, 1930.

8. Killermann, S. : Engler-Die natürlichen Pflanzenfamilien. Aufl. 2, Bd. VI, S. $122,1928$.

9. Peck, C. H.: New species of fungi. Bull. Torrey Bot. Club., Vol. XXXIV, p. 97-104, 1907.

10. Ramsвotтom, J.: A Handbook of the Larger British Fungi. p. 54, 1923.

11. ReA, C.: British Basidiomycetae. p. 449, p. 709, p. 743, 1922.

12. Saccardo, P. A.: Sylloge Fungorum. Vol. V, p. 374, 1887.

13. SACCARDJ, P. A. : Sylloge Fungorum. Vol. VI, p. 779, 1888.

14. SAccardo, P. A.: Sylloge Fungorum. Vol. XXI, p. 429, 1912.

15. Smith, W. G.: Synopsis of the British Basidiomycetes. p. 95, 1905. 


\section{歐 文論說摘要}

\section{故 工藤祐舜： 臺灣ノ紅樹林}

臺灣ノ紅樹林八其北部及西部海岸=發達シ、三科六種アル。高雄灣デハをかをて

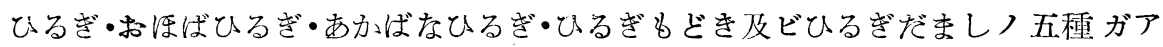
ル。ひるざだまし八灣內二至ル所ニアリ又可ナリノ喬木トナル。支柱根八お海ばひ るぎニヨク發達シ、文呼吸根八ひるを゙だまし二見事デアル。所謂膝狀ノ呼吸根八あ

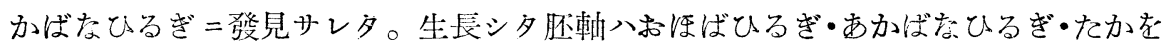
てひるぎ等デ觀察サレ夕。新竹州/紅毛デハ、河口ニてるぎだましトめひるぎトガ 發達シテ居ル。コ、ノひるぎだまし八低イ分枝七儿灌木狀デ滿潮時八海水ノ下二ナ ル。又めひるざハ小喬木デ、見事ナ長イ肧軸テツケテ居ル。北部基隆港ヤ富貴角二 モアルガ只めひるざカラ成リ、貧弱デアル。（昭和六年1一月十六日、臺北帝國大 學理農學部植物學呚窒二於テ)

\section{逸見武雄：數種ノ日本産菌類二關スル記錄}

本論文ニ於テ筆者八最近興味ヨ感ゼシ數種ノ菌類ニ就キ簡單ナル記錄ヨ發表セン 卜欲ス。

(1) Clavaria Miyabeana ITo ベになぎなたけ

本菌八北海道二於テ採集セラレシ標本二基キ今井三子氏无 1930 年ニ初メテ公表 シタル新種ニシテ、筆者八京都ニ於テ二包二亘リ採集セラレシ標本フ藏ス。子實體 八赤紅色ニシテ美麗ナリ。

(2) Clavaria amethystinoides PECK. むらさきははきたけもどき（新符）

本菌八むらさきははきたけ二似タレドモ、其色淡肉色又八淡紫褐色ナルラ異ニス。 高サ 1 乃至 $6 \mathrm{~cm}$. ニシテ分岐ス。

(3) Clavaria acuta Sow. しろゃりたけ

本菌、1929 年 9 月北海道二於テ探集七ラレタルモノガ、本邦ニ於ケル記錄ノ噫 矢卜ス。筆者モ亦同年 10 月京都府下ニテ探集七ラレシ 標本ヨ有ス。本菌八高サ 1-2.5 cm.八纖細ナル白色子賽體习形成ス。

(4) Pleurotus porrigens (PERS.) FR. すぎひらたけ（新稱）

本菌八歐洲二於テ針葉樹)切株二發生スルコトヨ報ゼラレタルモノニシテ、京都 附近二於テハ祄ノ腐朽株又八生活力向旺盛ナル杉ノ樹皮＝發生ス。子實體八雪白色 ナリ。

(5) Femsjonia luteo-alba FR. Kかはたけ（新棦）

本菌八腐朽七几樹木ノ樹皮二生ズルモノニシテ、濕閾ナル爿態ノ下ニテ膠質黄出 ニシテ無柄ナリ。特徽アル胞子ニョリテ容易ニ檢定シ得。 
(6) Clavaria pyxidata PERS. ふさひめははきたけ（新稱）

本菌八高サ 5 乃至 $6 \mathrm{~cm}$. ニシテ分肢シ、蒼白色ナレドモ淡黃褐色又八淡腥褐色 二變ズ。枝端小盃狀习呈シ其周園ヨリ更二小枝习生ズルヨ特徵トス。

(7) Clavaria Kunzei FR. しろひめははきたけ

雪白色ニシテ分岐セル子賽體ク生ズ。本邦ニ於ケル最初ノ記錄八今井三子氏 $=ヨ$ リ1929 年ニ發表セラレタルモノニシテ、氏八北海道產ノ標本ヨ檢セリ。筆者モ亦 同年京都府下二個所ニテ採集セラレタル標本ヨ藏ス。

\section{本田正次：やつしろらんノ學名ニ就テ}

かつしろらんへ 1909 年=牧野博士ガ肥後國八代產ノモノヨ檢シテDidymoplexis pallens GRIFFITH ト云フ印度ヒマラヤ産ノモノニ當テ、發表サレタ一種ノ寄生蘭 デ、花後ソノ花梗が法外二長クナルト云フ奇琪ノ垍性ヨ有スルラ以テ知ラレタモノ デアル。其ノ後紀州二產スルコトガ知ラレテ居タガ、最近適々紀州西牟婁郡岩田村

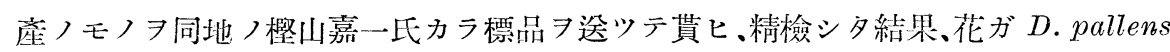
ニ比シテ遥カニ大キクテ、ソノ數ガ少イ事、苍ガ大キイ事、花色ガ暗褐紫色习呈ス 几事ナドヨ以テ明二別種卜認メタノデ、コレニ Didymoplexis nipponica HoNDV ト云フ學名习附スルコトニシタ。又本種八彼ノD. pallens ノ樣二竹ノ根二寄生ス ルコトナク、恐ラク或ル常綠濶葉樹種ノ根＝寄生スルノデアラウト云フ事モ探集者 樫山上ノ詳紐ナ觀察調查ニヨツテ明カデアル。

\section{江本義數：變形菌ノ一新種ニ就テ}

昭和六年春季ヨリ、余八枋木縣日光東照宮生物調查會〉委啒 スル變形菌類フ採集調查シタルガ、其內二未ダ記載セラレザル新種卜思ハル、モノ ヨ得タリ。

Enteridium Yabeanum sp. nov.

變形體八黑色ニシテ扁斥ナル團塊ヨナス。胞子囊ハ融合シテ著合胞子囊（Aethalium) ヨ形成ス、扁本ニシテ暗褐色 (Bister-Natal brown)*、不規則ナル形 フナシ。 厚サ約 3-8 mm. 、直徑 2-23.3 cm. (第一圖)。胞子囊壁八薄膜ニシテ淡褐色ナリ。 Hypothallus 八甚ダョク發達シ强靶ナル褐色ノ膜ヨナス。細毛體ハ之ヨ缺キ、多數

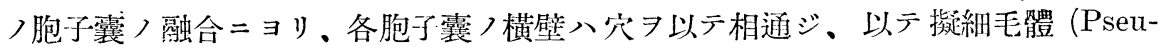
dokapillitium) ヨ生ゼリ（第二圖〉。胞子八團塊フナセル時ハオリリブ色 (Lightbrownish olive一Brownish olive $)^{*}$ フ呈スルモ、鏡下ニテ單一ノモノフ檢セバ無色 ナリ、直徑 6-7.5 $\mu$ 球形ニシテ、其全表面ニ八将狀突起アリ（第二圖）。

腐朽七儿つが材上:發生ス。昭租六年八月、杤木縣日光湯本二テ探集。

\section{今井三子：昇龍菌科ノ分類ニ對スル一寄與}

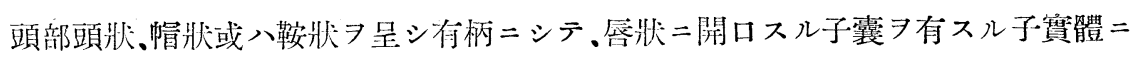

